\title{
Assim teria falado Zaratustra
}

ACIMA DO HOMEM E SEU TEMPO, a essência do pensamento do filósofo alemão Friedrich W. Nietzsche (1844-1900) ressurge no contexto da cultura contemporânea como referência à compreensão do espírito atual do nosso tempo. Ao voltar os ol hos ao nascimento do personagem - profeta do eterno retorno - vê se que a cena primitiva da inspiração de Zaratu stra foi um instantequebrilhou àfrente do andarilho N ietzsche, como o presságio de um novo dia:

“A concepção fundamental da obra, o pensamento do eterno retorno, a mais elevadaforma deafirmação quesepode em absoluto alcançar é de agosto de 1881: foi lançado em uma página com o subscrito: ' seismil pésacimado homem e de seu tempo'. Naquele dia eu caminhava pelos bosques perto do lago Silvaplana; detive-me junto a um imponente bloco de pedra em forma de pirâmide, pouco distande de Surlei, então veio-me este pensamento." ${ }^{1}$

Sua circunstância existencial em decorrência da gradual perda da visão, aliada a impedimentos físicos, transfigurou o homem que havia rompido com Richard Wagner e redimensionado as influências de Schoppenhauer. Escreveu Humano, D emasiado Humano, um livro para espíritos livres, em 1878, trabal ho concluído com a publicação da segunda continuação 0 Andarilho e sua Sombra, em 1880. A filosofia a golpes de martelo se desenhava como a marca pessoal do ex-professor deFilologia daUniversidade da Basiléia.

Nietzsche vislumbrou as tantas auroras que não brilharam ainda, em 1881, epor sugestão de seu amigo Peter Gast, chamou de A urora

Francisco E. Menezes Martins

Doctor en Ciencias de la Información Universidad Complutense de Madrid Vice-Diretor da FAMECOS/ PUCRS seus últimos escritos. O livro se revela uma nova esperança de vida a um homem que entre o azul do Mediterrâneo Ligúrico e os penhascosgenoveses vislumbrou: “todauma 
sucessão, todo um mundo de novos dias.(...) Em uma transvaloração de todos os valores , em um desprender-se de todos os valores morais, em um confiar e dizer sim a tudo o que até aqui foi proibido, desprezado, maldito."2 Sobre A urora, comenta em Ecce Homo:

"Minha tarefa de preparar a humanidade para um instante de suprema tomadadeconsciência, umgrandemeiodia em que ela ol he para trás e para adiante, em que ela escape ao domínio do acaso e do sacerdote e coloque a questão do por quê? Doparaquê? Como um todo(...). A perda do centro de gravidade, a resistência aos instintos naturais, em uma palavra'a ausênciade si'- a isto se chamou moral até agora... ComA urora iniciei aluta contra a moral da renúncia de si."3

Longas caminhadas pelas manhãs e o andarilho-filósofo amadurecia seu pensamento como o sol que progressivamente iluminava e aquecia o dia, sucedendo as brumas. A mensagem de Zaratustra é um ataque direto ao idealismo metafísico que atribui ao mundo a existência de uma finalidade, de um significado. Ao exaltar a vontade depoder (potência), Nietzsche nega uma meta distinta às colocadas livremente pelo próprio homem. Este nihilismo implica na perda de validade de todos os valores supremos e ignora a negação como mentira. Esta negação, ao tornar-se consciente, gera o próprio nihilismo.

A Razão, a Ciência, a História e o Progresso tornavam-se valores supremos e apresentavam-se como os substitutos da idéia de "mundo verdadeiro", que a partir de Platão passou a conviver com o "mundo aparente".

Em 0 Crepúsculo dos Ídolos, N ietzsche refereseà história de um erro, no qual este mundo é acessível somente ao sábio e ao virtuoso, pois ele é este "mundo verdadeiro", ao inventá-lo e por passar a viver nele:
“El 'mundo verdadeiro' es una idea que ya nosirveparanada, queyani siquiera obliga, una idea que se ha vuelto inútil, superflua; en consecuencia es una idea que ha sido refutada: eliminémosla.

(Día claro; desayuno, vuelta del sentido común y de la serenidad alegre; Platón se pone rojo de verguenza y todos los espíritus libres arman un ruído de mil demonios.)

Hemoseliminadoel mundoverdadeiro? Qué mundo ha quedado? El aparente? $\mathrm{No}$ ! al eliminar el mundo verdadeiro hemos eliminado también el aparente.

(Mediodía; instante de la más breve sombra; fin del más largo error; punto culminantedelahumanidad; comienza Zaratustra.)." ${ }^{4}$

\section{Pensar Nietzsche e a Cultura Contem- porânea}

Ruínas - Do "mundo verdadeiro" da modernidade só restam ruínas, mas sobre estas ruínas se erguem novas tábuas de valores. A pós-modernidade é terra fértil para a proliferação do efêmero. $\mathrm{N}$ ietzsche-Zaratustra levantou a voz para falar da grande saúde para enfrentar os tempos futuros.

Voltar aos pré-socráticos - O devir perdeu sua inocência, sua capacidade de tornar-se, de chegar a ser. Era necessário vislumbrar a época na qual a vida era filosofia e a única realidaderadical. A Razão dotou o mundo de um sentido que ele jamais possuiu.

Resgatar a Inocência do Devir - Hoje, é necessário novamente resgatar a inocência do devir, isto éliberá-lo de qual quer meta ou finalidade. A comunicação daerainformática não deveria pretender formatar o devir com suas plataformas tecnolúdicas.

Ser eEterno R etorno - A maisalta expressão da 
vontade de poder é atribuir ao devir a condição do ser. No eterno retorno o ser se afirma como devir em seu eterno retornar. A idéia é a de um devir cíclico.

A Grande Saúde - O homem e suas próteses alteram a idéia de evolução de Darwin. 0 laboratório de experiências dos cientistas abandona o espaço para miniaturizar-se no corpo. Para Virilio, é a transfiguração da "grande saúde" de Zaratustra. Onde está a seleção natural ? Sobreviveo maisapto? Entre os triunfos da elevação da qualidade de vida surge a questão: existe o devir cyborg?

Filosofia e Comunicação - Quando o conhe cimento é transformado em assunto de programas deauditório, como diz Lyotard, e o conhecimento não traduzido às linguagens da mídia parece ser o excesso, não seria o momento de revisar nossos conceitos de informação esaber? Quando algunsfilósofos viram as costas à comunicação, tentando continuar a enquadrar seus pensamentos em categorias, ignorando que há fragmentos dotados de sentido próprio formando novos valores que por serem não-racionais não deixam deser humanos, demasiadohumanos, e, portanto, área de interesse dos pensadores da fil osofia da vida, não seria o momento de revisar nossos conceitos de filósofo e de filosofia? Quando alguns jornalistas se limitam a "abrir aspas" e repetir o discurso paranão secomprometerem, equandoalguns editores-chefes acreditam que a verdade é a média aritmética das capas dos principais jornais, epor isso, exaltam felicidadequando seu jornal é igual aos demais, não seria o momento de revisar nossos conceitos de jornalista e de jornalismo? Quando a performance da imprensa parece ser mais importantequeosacontecimentosnoticiados e que o simulacro baudrillardiano em sua indiferentevirulênciapautaasuperfíciebanal do corroídotecidosocial, aindasepodepensar embuscadeverdadeou vontadedeliberdade no jornalismo?

Quando a criatividade parece ser privilégio de alguns publicitários e marketeiros e que seus conceitos orientam as pessoas em geral, no que Virilio chama de "metadesign dos costumes" e quando a massa espera que instituições "inteligentes e de bom gosto" sejam seu pastor e criador de " próteses de personalidade e autolocalização social" no caótico cotidiano pós-moderno, não seria o momento de revisar nossos conceitos de criatividade, inteligência, gosto e do próprio conceito de conceito ?

Assim Teria Falado Zaratustra !

Notas

1 NIETZSCHE, Friedrich. Ecce Homo: como alguém se torna o que é, São Paulo, Cia. das Letras, 1995, p. 84

2 NIETZSCHE, Friedrich. Op.Cit. p. 79

3 NIETZSCHE, Friedrich. Op.Cit. p. 79-80

4 NIETZSCHE, Friedrich. El 0 caso de los Idolos: como se filosofa a martillazos, Madrid, A.L. Mateos, 1993, p. 62

Bibliografia

NIETZSCHE, Friedrich. Así Habló Zaratustra: un libro para todos y para nadie, Madrid, A.L. Mateos, 1993.

NIETZSCHE, Friedrich. Aurora, Madrid, A.L. Mateos, 1992.

NIETZSCHE, Friedrich. La Voluntad de Poderío, Madrid, Edaf, 1981.

NIETZSCHE, Friedrich. El Eterno Retorno; Así Habló Zaratustra; Mas alla del Bien y del Mal; Obras Completas, vol III, Buenos Aires, Aguilar, 1965.

NIETZSCHE, Friedrich. Humano, Demasiado Humano: un libro para espiritus libres, Madrid, A.L. Mateos, 1993.

NIETZSCHE, Friedrich. La Genealogia de la M oral, Madrid, A.L. Mateos, 1993.

SALOMÉ, Lou-Andreas. Nietzsche em suas obras, São Paulo, Ed. Braziliense, 1992. 